\title{
Social Work Education in Pakistan: Issues and Future Opportunities
}

\author{
Nasreen Aslam Shah \\ Social Work \& Women's Studies \\ University of Karachi
}

\begin{abstract}
Social work is a professional and academic discipline that committed to improve the quality and prosperity of individuals, groups, and communities through scientific knowledge, policy, community organizing, direct practice and teaching. Pakistan is very fortunate to have a good start of professional Social Work; the first social work training began in the year 1953. Social work education in universities started in 1954 and its aim is to provide trained social workers equipped with the basic knowledge and skills to assist government and private agencies in the development and implementation of social welfare programs. This study presents an overview of the brief history, current issues and future opportunities of social work education in Pakistan. This study emphasizes some of the significant issues that cause concern, such as the social work education and practice appropriate for Pakistan society, teaching and learning, fieldwork and supervision, certification and licensing for social workers. It's important to talk about some issues of concern and the direction in which a strong and sound social work education can be developed.
\end{abstract}

Keywords: Social Work Education; Issues and opportunities, Pakistan.

$$
\begin{aligned}
& \text { تلخيص }
\end{aligned}
$$

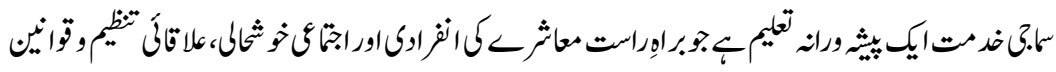

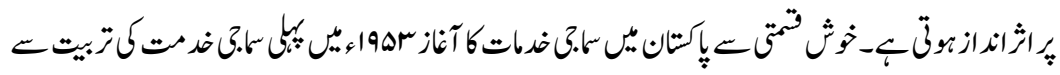

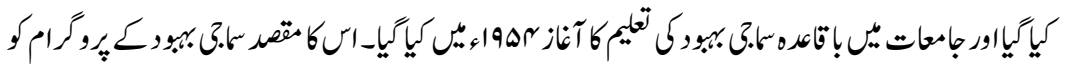

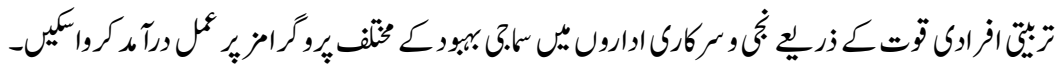

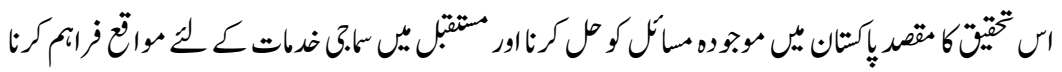

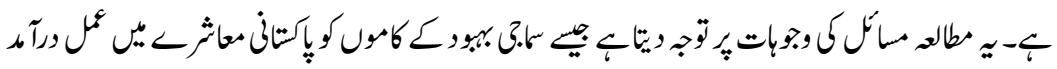

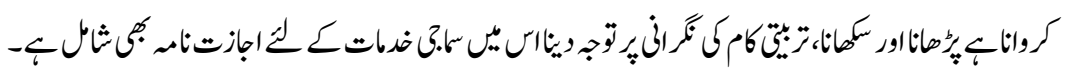

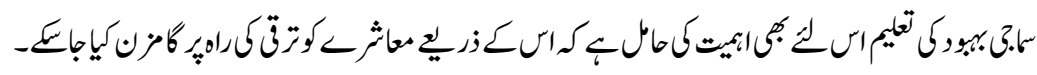

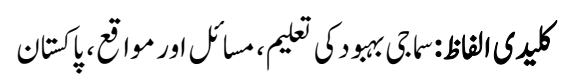




\section{Introduction}

The education system in Pakistan is commonly criticized for the elimination of the marginalized groups and for lack of significance and native knowledge. However, throughout British rule, from 1700 to 1947, Pakistan's education policies reinforced the earlier selective tendencies. By the early twentieth century, alternative castes and marginalized people recognized the benefit of education and managed to get proper education. It is hoped that with addition of these groups in the education system for proper education; the Pakistan education system will become more appropriate, contextual and local in its nature sufficiently contributing to the national development.

Social work education as a river of the higher education system is over a hundred years old in the world and developed extremely in past decades (Midgley, 2000). In Pakistan, it's almost done sixty-five years. However, the position of social work education in Pakistan, particularly of its knowledge base, remains debated and remarked upon in published work as well as in academic gatherings. Social work education as a profession is commonly considered as an emerging profession because of, the absence of local course to knowledge component and lack of connections between classroom learning and field realities.

Pakistan is very fortunate to have a good beginning of professional Social Work. In Pakistan, professional social work owes its origin to a short-term training course on social service organized by the social service at Karachi. The training course included those men and women who were willing to volunteer them for social service. Till that time social workers did not get any salary of remuneration for their work. It was simply a social service to the needy people guided by the principle of humanity. Later on, the social work departments were established in the year of 1954 in Lahore. The department started a course of professional training in social work. In the year 1961, another department of social was established at University of Karachi (Dr. Mohammad Khalid, 2007).

Sixty five years of professional Social Work in Pakistan has been marked by few successes and too several travails that justify a serious debate on what the future holds for a 'profession' besieged by many internal and external limitations and considerations as well as Inbreeding in manyorganizations, lack of local literature, weight age for fieldwork, and therefore the undeniable fact that most social work educators don't seem to be practitioners in contrast to the counterparts in many developed countries. Hardly any real attempt created for the development of field, non-professionals at education and training, lack of standards in education and training, and for establishing a 'National Council for Social Work Education and Training in Pakistan. 
This study presents an overview of the brief history, current issues and future opportunities of social work education in Pakistan. This study emphasizes some of the significant issues that cause concern, such as the social work education and practice appropriate for Pakistan society, teaching and learning, fieldwork and supervision, certification and licensing for social workers. It's important to talk about some issues of concern and the direction in which a strong and sound social work education can be developed.

\section{Objectives}

- To look in to the history and development of social work education in Pakistan

- To identify the current problems, and future opportunities of social work education in Pakistan

- To draws the recommendations for social work education

\section{Social Work Education: A Global Overview}

Being a world profession, education for social work gets place in the majority of the countries within the world. It has a reach of around three thousands schools/departments of social work in over 193 countries in the world (Midgley, 2000a). Besides the usual social work, global social work is educated in schools, colleges and universities of social work and cross-national cooperation between training programs is common practice (Pawar, 2014). Social work profession has been mutually explained by the International Association of Schools of Social Work (IASSW) and the International Federation of Social Workers (IFSW) as follows: The social work profession promotes social change, problem solving in human relationships and empowerment and liberation of people to enhance well being, vitalizing theories of human behaviour and social systems. Social work intervenes at the point where people interact with their environments. Principles of human rights and social justice are 'fundamental to social work' (Ordorika, 2008). The development of social work education is closely linked with the development of social work profession (Estes, 1997).

Basically, in terms of social work profession and social work education; the world is divided into two parts. The Northern part which includes USA, UK and other European countries and the Southern part which comprises Asian, Middle-East Asian, African and other third world nations. It was the social crisis in the Western Europe and North America in the 18th and 19th centuries, which led to the creation of social work as an institution and profession (Bernstein, 1995).

This social crisis in the western countries which tore a vent through many western societies in the 18th and 19th centuries is commonly referred to as the industrial 
revolution'. Rapid industrialization and urbanization transformed the lives of all people (Farley and Smith, 2006). Social work emerged as a response to this crisis. State social welfare initiatives such as schemes for public sanitation, education, juvenile correction, public workhouses accompanied with legislation as well as new mechanisms for recording population change originated in the 19th century. The social work activities were financed and run by philanthropic agencies and statutory agencies such as courts, hospitals and workhouses in this period (Stroup, 1980).

In 1870 s when a scheme for training housing managers responsible to help tenants in Britain was started by Octavia Hill the need for a more systematic training of social work education was felt. As a result systematic training started at Women's University settlement in London in 1890s (Axinn\& Levin, 1975). In the USA the first brief training course comprising lectures, observation visits and field work was started by the Charity Organization Society in 1898. This program ultimately developed into the New York School of Social Work (Compton, 1980).

The Second World War had caused much destruction to the peace and harmony in the third world countries. As a result, the UN sent social work consultants from the West to third world countries to provide all kinds of support. These consultants visited different ministries, public and private sectors and NGOs of the third world countries. Based on the observations made by these consultants a twofold system was developed for training the 'Trained Social Workers'. One to bring the experts from the west, and the other to send the persons from third world countries to the west, who would come back and help their own (Midgley,1978) to control and prevent the situation from worsening.

The social work professionals from the west and from the third world countries who were trained in the western countries attempted to develop theories, knowledge and models and started to apply them in the third world countries. But the socio-cultural milieu and indigenous aspects of the third world countries did not match those of the west. Midgley (1978a) argued that western ideas, technologies and institutions replicated in the developing countries were actually to serve the interests of developed countries and establish a new colonialism in a more subtle and effective way in order to have power over them.

The local pattern of social work practice is challenged by the globalization of economies and technologies likewise because of the variety of socio-economic, culture, traditions, ethnicities and religions in numerous regions of the world (DuBoi and Miley, 2005). Social work in many countries also faces variety in religion, traditional faith, culture and social developments. Social work practice is different among ethnic groups. This diversity of customary culture creates multicultural social work practice difficult and tricky. A comparable condition 
takes places in the thought-out world. Local social work practice with one ethnic group may not fit and be appropriate to another. A general idea of the changing models of social work education, resulting from the changing background of socio-economic and political systems in different country to country (Conrad, 1999).

\section{Development of Social Work Education in Pakistan}

As a nation, Islamic Republic of Pakistan is extremely numerous in cultural characteristics. Influenced by the West, it's pluralistic and democratic with a number of political ideologies. Therefore, the Pakistan social work professionals are faced with a very complicated certainty. There is interaction of the many socio, cultural, economic, political and even geographical aspects at intervals and from one area to the other. Individuals within Pakistan are divided on ethnic, linguistic, cultural, regional, caste and religious lines.

This variety is additional complex by the very reality that a number of agreements urbanized, industrialized and modernized faster as compared to the others. This complicated combine of practice and contemporarily composes it nearly impracticable to make one overarching method to suit all. Additional, several parts get politicized faster than others. In this environment, one cannot expect one Pakistan model to fit all the areas of social work education and practice. Previously, general prejudice of helpless groups was due to their features such as religion, caste, sex, ethnicity, age, health and economic background (Shireen, 2002).

These procedures have to lead to social dislocation, ecological destruction, and the cleaning out of cultural and natural variety. In such situation poverty, social difference and ecological disasters are on the increase. Action groups hoping towards sustainable and people-centered development encouraging the prices of social equity, local self-governance, democratic pluralism, local people's participation, self-sufficiency and harmony and mutual social self-motivated are rising in new social movements.

As understanding the reality and difficulty of Pakistan's society, with the future socio-economic and political movements and its consequence on society, the social worker has an important task to play in the circumstance of the rebirth of the civil society. The wide concerns for social work are equity, social justice, harmony, directing the activities to maintain the search of the deprived groups to get their basic needs. Social work professionals are likely to take action to the social realism of the current society. Social work training requires to obtain the note of all these related issues to include this in its curriculum, classroom 
teaching, and field practice and research studies to make the learning applicable and more relaxed.

\section{Structure and Content of Social Work: Pakistan}

According to Higher Education Commission of Pakistan (2014), the structure of Social Work Education in Bachelor (BSW) and Master's Degree (MA) are credit based in various departments in the university and faculties of social work in Pakistan. The Bachelor of social work is the primary professional degree in social work in Pakistan, the key aim of the Bachelor degree is to prepare the social workers with scholarly person observe individual, families, groups, organizations, and communities, whereas the Masters level social works aim is to arrange the graduates for the higher practice and to develop the expertise in the optional fields. The least obligation for a professional position in this field is a bachelor's. Bachelor's degree in social work is a three/two-year course open for all those who have passed their Pre- University education or its equivalent qualification. A graduate in any discipline will be a part of the Master's Degree course in Social Work which is of two-year duration. The admission to the MA in social work degree is open to all candidates irrespective of that possess a bachelor's degree. Several universities in Pakistan held an entrance examination at the national level to select the students. However, very few universities of social work following the selection process.

The social work degree at the bachelor's level carries a most of eighty credits across theory and also the practice parts. Number of the faculties follow three days of theory category and three days of observe within the bachelor's degree level, whereas some others follow two days of field practice. There are not any block placements parts of a month-long add workplace or community or the department of the government or a hospital within the bachelor's degree level however there's a provision for the study tour with supervised instruction by the faculty members. At the Masters' level, the social work syllabus will take issue from university to university and also the specializations offered by the faculties. The Master's course in social work bearing 80-90 credits of demand unfold across four semesters. Out of the overall variety of credits, one third is reserved for the munitions practicum. Another time there's a variation within the specializations provided across the faculties in Pakistan. Many colleges of social work and departments offer the various specializations like Human Resource and Personnel Management, Community Development/ Social Development and Medical and psychiatrically social work. 


\begin{tabular}{|c|c|c|c|}
\hline \multicolumn{2}{|c|}{$\begin{array}{l}* * \text { Major courses including } \\
\text { research project/Field Work }\end{array}$} & \multicolumn{2}{|l|}{ Elective Courses within the major } \\
\hline \multirow{2}{*}{\multicolumn{2}{|c|}{$\begin{array}{c}\text { 12-14 courses } \\
\text { 39-45 Credit hours } \\
\end{array}$}} & \multicolumn{2}{|l|}{4 courses } \\
\hline & & 12 Credit Hours & \\
\hline Subject & $\begin{array}{l}\text { Cr. } \\
\text { hr }\end{array}$ & Subject & $\begin{array}{l}\text { Cr. } \\
\text { hr }\end{array}$ \\
\hline $\begin{array}{l}\text { 1. Social Case Work } \\
\text { 2. Social Group Work } \\
\text { 3. Community Organization } \\
\text { \& Development } \\
\text { 4. Social Research } \\
\text { 5. Social Welfare } \\
\text { Administration } \\
\text { 6. Social Action } \\
\text { 7. Social Gerontology } \\
\text { 8. Criminology } \\
\text { 9. Field Work \& Report-I } \\
\text { 10. Field Work \& Report-II } \\
\text { 11. Field Work \& Report-III } \\
\text { 12. Field Work \& Report-IV } \\
\text { 13. Research Project / Thesis }\end{array}$ & $\begin{array}{l}3 \\
3 \\
4 \\
4 \\
4 \\
6\end{array}$ & $\begin{array}{l}\text { Four courses one from each } \\
\text { group: } \\
\text { A. Case Work Specialization } \\
\text { 1. Medical Social Work } \\
\text { 2. Psychiatric Social Work } \\
\text { 3. School Social Work } \\
\text { 4. Social Work with Special } \\
\text { People } \\
\text { 5. Social Work and Correctional } \\
\text { Services } \\
\text { 6. Drug Abuse Prevention } \\
\text { 7. Child Protection } \\
\text { B. Group Work Specialization } \\
\text { 1. Youth Welfare } \\
\text { 2. Social Work with Family } \\
\text { C. Community Development } \\
\text { Specialization } \\
\text { 1. Rural Development \& Local } \\
\text { Government } \\
\text { 2. NGOs Management } \\
\text { 3. Population Welfare } \\
\text { 4. Urban Development } \\
\text { 5. Gender \& Development } \\
\text { D. Social Welfare Administration } \\
\text { Specialization } \\
\text { 1. Project Planning } \\
\text { 2. Comagement } \\
\text { 3. Labour Welfare } \\
\text { Risk Reduction (CBDRR) } \\
\text { a }\end{array}$ & $\begin{array}{l}3 \\
3 \\
3 \\
3 \\
3 \\
3 \\
3\end{array}$ \\
\hline
\end{tabular}

Source: Higher Education Commission, Islamabad-Pakistan (2015) 


\section{Methodology}

This research paper attempts to summaries the brief history, current issues and future opportunities of social work education in Pakistan. The secondary data was collected through a variety of sources such as websites, Economic survey, books and journals.

\section{The Problems and Challenges to Professional Social Work in Pakistan}

The following problems and challenges faced to social work education in Pakistan which require to be addressed jointly for rising the standards, enhancing the identification of the profession and developing literature in consonance with the social context.

\section{Recognition of Professional Social Work}

Lack of public and government identification of social work as a profession may be a crucial absence that has a lot to try with its future views in Pakistan. The idea of the professional social work within the people's mind is a challenge to an idealized picture of a standard social worker who has the sterling qualities of the heart rather than of mind. The proposal of a paid professional social worker is still an abhorrence to the majority in Pakistan who even now cling to the idea that doing social work is essentially a voluntary activity of a selfless sort. Under Pakistan circumstances service and sacrifice, this is noble and without any wage, is looked upon as higher.

\section{Low Established Level}

The current level of Pakistan social and welfare services is very low bywhich the majority of the unpaid welfare organizations lack the required resources to fulfill number of the fundamental human desires offolk. Even the Federal Social Welfare which helps monetarily to voluntary organizations do not promote the reason of professional social work. In fact, the department that uses a huge range of specialists has not given correct illustration to the professional social workers. It's right that proper education for social work has taken basis and presents graduate courses nowadays, by several different ways that are teaching training in connected fields both at the graduate and undergraduate levels. It's additionally true that variety of agencies do exist that still to support the reason of professional social work. However not denying the actual fact that both Pakistan social work education and its professional agencies are spreading a system of social work that gets the inspiration principally from American social work philosophy with its ideas, techniques, structure, and goals (Anwer, 2008). 


\section{Lack of Local Literature}

The key disadvantage of social work education in Pakistan is its lack of ability to adequately localize its knowledge-base. The essential teaching objects with regard to interventionist ways (the divine of social welfare work, group work, and community organization) continues to be primarily Western. The challenge, as mentioned before, has not been met and there's typically a lingering doubt within the mind of the many social work educators and trained social workers whether or not social work in Pakistan will afford to be solely involved with specific people, groups, and communities, the issues are confronting enormous masses of individuals. Several of issues that are known as issues of the socially oppressed and economically disadvantaged sections can't be known as modify mental problems. The social and cultural context of those issues is well on the far side the reach of moral-ethical and /or psycho-social paradigm of intervention (Waseem, 1982).

Since the social work literature, methods of practice, approaches, theories, have been greatly borrowed from western countries, so we must develop the local approaches too. This needs that the academicians and practitioners must document their experiences so as to make possible the procedure of developing native knowledge and information.

\section{Lack of Local Based Code of Ethics}

The professionals alone haven't, however, no heritable any main place to form and prepare social policies or to administer social organizations. For a second time, the professional cluster itself has not developed any social code that the profession conjointly ought to recognize and examine because of the basic feature of their profession. Visible of the dominance of foreign influence on the social work in Pakistan and its lack of combination with the cultural mores of Pakistan society, there's no agreement on the knowledgeable code of ethics for the practice of social work (Safdar, 1977). The profession has not develop consciousness of kind and has not created a standard platform to precise its purpose of reading on broad problems and issues attempted by the society. Moreover, the educational institutions provide only a few courses on social administration, social planning, and social policy, and most of the prevailing courses did not develop intellectual interest and ability to push research orientation.

\section{National Council for Social Work}

We must have national and provincial levels commission to keep the identical standards of education and provide authorization to organizations as well as to practitioners. If not an identical method of authorization on all Pakistan bases is 
developed and implement, the development of social work education and programs on sound lines is possible to proceed extremely gradually for a long time. A number of committees recommended the establishment of a national and provincial social work councils, but no action seems to have been taken in this behalf so far.

\section{Social Work Educators are not Practitioners}

When we talk regarding social work as a profession like medicine, and engineering etc. The teachers of medical universities perform their profession by visiting hospital along with the medical students, professors of professional involvement in practice and update their knowledge levels, improve their competencies to contract with the problems (Kirst,2003) In social work, the holistic sight on teaching, practice and research is lacking very much, majority Social Work Educators are found to be contented in conservative classroom teaching and hardly ever found in practice and research fields. Social work professionals also teach, lead and train the students of social work like medicine or law students will only be trained by medical/ law teachers, professional students only may be capacitated by the graduates likewise same are going to be appropriate for social work profession.

\section{Lake of Standards of Education and Training}

It must standardize the value of education and training that are offered by various universities of social work throughout the country. Social work departments differ from each other in terms of curricula, common course versus specialization offered, activities, focus, duration, training inputs of fieldwork parts and so on. There ought to be a least standard of education and fieldwork training inputs offered to students in universities (Thomas, 2010). Across the state, no university is adopting homogeneous program, tips and other standards. Many departments are not giving any priority to workshop; merely the students are being awarded the degrees. Certainly standard of education in social work is inadequate.

\section{Future Opportunities of Social Work Education in Pakistan}

At present, the development sector is basically managed by the social welfare department and non-governmental organizations (NGOs) that are performing pioneering work to the development of the society. Someone with a degree (preferably a Master degree) in Social Work is vastly most well-liked in developmental organizations and NGOs. In additional words, it is aforementioned that NGO sectors, additionally because the development sectors, are being conquered by the professional social workers. As a way, because the pay of an expert social worker in development sector is concerned-it differs from 
organization to organization. Vast employment opportunities offered for social workers in private as well as public sector organizations. Though it was considered a low paid profession earlier, recently several organization offices are taking over social responsibilities and they look for good capable social workers who are paid on par with the other workers.

Career opportunities in social work would depend on an individual's space of specialization. Social workers who specialize in the area of human resource management can get jobs in the Personnel, Human Resource Management (HRM), Welfare departments of factories and commercial organizations, as executive officers, trainee officers, welfare officers and social security officers. Trained professionals will get government cadre jobs, semi-government activities, government organizations as labor welfare officers, welfare officers, social workers etc (Zofia, 1977). There are also NGOs and organizations giving various services to different parts of the society. NGO's would like trained social employees to figure in varied fields. Social employees may also take up teaching assignments. After many years of expertise, one will even become an adviser with varied organizations and may conjointly begin freelance work. Social workers will pursue a career as a counselor in healthcare, environmental protection, community policing etc. They will concentrate on kid welfare and family services, mental state services, public help, medical social work, community organization, welfare work, coming up with and policy development or welfare administration.

Globalization and the new signal of industrial advances, joined with worldwide mutuality between and among people, groups, and states, are having a wonderful consequence on social work education and practice all over the world. With growing world social issues, social work professionals endlessly busy to find solutions to each native and world issues. This trend is mirrored within the social work profession's involvement in a sort of global measurements of apply and with varied organizations involved with world challenges and problems. Immense opportunities are obtainable for social workers abroad (Cree, 2003).

Globalization extended the capacity of service for students choosing for social work as their career Social workers have a novel talent set that's in demand in several elements of the planet, and a few might feel their skills can be higher applied in a world setting. Whereas jobs in domestic and international social work are similar, the approach to life and cultural challenges are completely different. Social workers distinctive skills and versatile approaches to problem-solving will facilitate develop human potential in places wherever folks are burdened and make peaceful, mutual solutions to strife-filled things(DuBois, and Miley,2005) The benefits of social service jobs abroad will outweigh the shortage of a monetary reward. Success and also the satisfaction that comes with it all told 
fields of social service square measure betting on the data of, and familiarity with, human behaviour.

Challenging yourself to be taught in a very totally cultural circumstance through social work overseas can extend your viewpoint and practices, demonstrate the new methods that to follow previous skills, show alternative ways professionals treat apparently universal issues and conditions. The present state of social work skilled development is characterized by two realities. There's an excellent deal of ancient social and psychological analysis (both qualitative and quantitative) being disbursed primarily by university-based researchers and by researchers based mostly in institutes, foundations, or work agencies. Meanwhile, several social work practitioners still look to their own expertise for data. This can be a continuation of the controversy that has persisted since the get-go of the profession within the initial decade of the $21^{\text {st }}$ century.

\section{Recommendations}

To promote social work education in Pakistan, the research suggests the following recommendations:

- The model from top to bottom must be amended in the country. There's additionally a need to focus on published and unpublished materials of nongovernmental organizations which are very helpful for knowledge improvement. Besides this, another local source that social work knowledge is made by departments of social work education.

- Discussions between social work and allied authorities, academicians, practitioners and activists to come up for research and long-term partnership.

- Social Work Education is being formed by University Departments; the standard of University Departments would outline the standard of Social Work Education. If the university departments of federal and province level have a joint vision and mission then it will result a more robust expression of the Social Work Education.

- Its ability to produce more learning opportunities through classroom communication library and internet resources.

- Its efforts to encourage scholastic performance among staff and students.

- The national and provincial level lobbying efforts to deal with the issues and challenges in a very systematic manner by strengthening social work education in Pakistan. Social work education will be formed within the simpler manner to beat the issues and challenges. At last, The Human Resources must be designed through coaching \& development, consolidated by observe, controlled in sustained action and amalgamated into character. 
- The current model of social work education in developed countries does not suit the requirements of developing countries, therefore, there is an excellent need to advance local syllabus in all universities.

- The model of social work education should suit the historical and cultural origins of people.

- It ought to gather the socio-economic necessities of the bulk inhabitants of the country, especially the challenge of poverty.

- The idea of development should be obviously outlined, maintaining in view the prevailing truths and therefore, the future line of social change, and

- The structure, content, and procedure of social work education, must be linked with the aim, and their implication in the field be kept under constant review.

\section{Conclusions}

Seventy years of professional social work in Pakistan has been marked by few achievements and too many failures that demand a serious debate on what the future holds for a 'profession' stressed by several internal and external constrains and considerations. During the period of seven decades after its inception in Pakistan achievements, have several problems and challenges faced by the country. In this paper the authors tried to combine the problems and challenges, and recommendations for addressing those problems and challenges. Teachers, practitioners and learners should come together with collective vision and mission to overcome all those problems and challenges to strengthen the social work education in Pakistan.

Professions supported the relation like social work should have its knowledge domain really reflective values, culture, issues of society within which it is to be instructed and practiced. Concerning social work education in Pakistan, it'll be inappropriate to mention that social work educators haven't more matured the requirement of indigenizing social work information. It, however, is seen in the writings of the professionals that there is want of time and its dissemination. However, it was found that organized efforts were not made to determine the causes for the lack of local knowledge in Pakistan.

\section{References}

Alam, Anwer (2008). Community Development and Social Welfare. Peshawar, Pakistan: New Awan Printers.

Axinn, J. \& Levin, H. (1975). Social Welfare: A History of the American Response to Need. New York: Harper and Row, Inc. 
Bernstein, A. J. (1995). Redefining Social Work's Emphasis on the 'Social': The Path to Development, In: International Social Work, vol.38, pp.53-67.

Compton, B.R. (1980). Introduction to Social Welfare and Social Work: Structure, Function, and Process. Homewood, IL: The Dorsey Press.

Conrad, I.F. (1999). Education for Social Work. New York: Russell Sage Foundation.

Cree, V.E., (ed) (2003). Becoming a Social Worker, London, Routledge.

DuBois, B. \& Miley, K.K. (2005) Social work: An Empowering Profession. Boston, Pearson Education Inc.

DuBois, B. \& Miley, K.K. (2005a). Social Work: An Empowering Profession. Boston, Pearson Education Inc.

Estes, R.J. (1997). Social Work, Social Development, and Community Welfare Centers in International Perspective, in: International Social Work, vol.40:1, pp.43-55.

Farley, O.W and Smith, L.L. (2006) Introduction to Social Work. (10 ${ }^{\text {th }}$ edition). Boston, Pearson.

HEC. (2015). Curriculum of Social Work BS/MS (Revised 2015), Higher Education Commission, Islamabad, Pakistan, p.12.

Kirst-Ashman, K. (2003). Introduction to Social Work and Social Welfare: Critical Thinking Perspectives. Pacific Grove, USA: Cole-Thomas Learning.

M, Waseem (1982). Local Power Structure and the Relevance of Rural Development Strategies: A Case Study of Pakistan. Community Development, vol.17, pp.225-233.

Midgley, G. (2000). Systemic Intervention: Philosophy, Methodology and Practice. New York, Kluwer Academic.

Midgley, G. (2000a). Systemic Intervention: Philosophy, Methodology and Practice. New York, Kluwer Academic. 
Midgley, J. (1978). Developmental Roles for Social Work in the Third World: The Prospect of Social Planning, in: Journal of Social Policy, vol.7:2, pp.173-188.

Midgley, J. (1978a). Developmental Roles for Social Work in the Third World: The Prospect of Social Planning, in: Journal of Social Policy, vol.7:2, pp.173-188.

Ordorika, I. (2008). Globalization and Higher Education: The Economization of the University. Higher Education in the World 3. P. Taylor. London, Palgrave Mcmillan

Pawar, Manohar (2014). Social and Community Development Practice. Delhi, India: Saurabh Printers Pvt. Limed.

SafdarZaman (1977). Community Development. Peshawar, Pakistan: Taj Publishers.

Shireen, Rehmatullah (2002). Social Welfare in Pakistan. Karachi, Pakistan: Oxford University Press.

Stroup, H.H. (1980). Social Work. An introduction to the field. New York, American Book Co.

Thomas Kuby. (2010). Non-Governmental Organizations Work in World BankSupport Project. Washington, DC., USA; Oxford Press.

Zofia, B. (1977). The Nature of Social Work, London: Oxford Press.

Dr. Nasreen Aslam Shah is Meritorious Professor in the Department of Social Work and Director, Centre of Excellence for Women's Studies, University of Karachi. 